\title{
Aplikasi Panduan Fitness Untuk Manula Menggunakan Teknologi Augmented Reality
}

\author{
Des Suryani ${ }^{1}$, Dedy Irfan $^{2}$, Ambiyar $^{3}$, Abdul Syukur $^{4}$, Zulfajri $^{5}$ \\ Program Studi Teknik Informatika, Fakultas Teknik, Universitas Islam Riau ${ }^{1,4,5}$ \\ Program Studi Pendidikan Teknologi Kejuruan, Fakultas Teknik, Universitas Negeri Padang ${ }^{2,3}$ \\ des.suryani@eng.uir.ac.id ${ }^{1}$,dedy@gmail.com², ambiyar@ft.unp.ac.id ${ }^{3}$, abdulsyukur@eng.uir.ac.id ${ }^{4}$, \\ zulfajri0609@student.uir.ac.id ${ }^{5}$
}

\section{Article Info}

History :

Dikirim 06 November 2020

Direvisi 16 November 2020

Diterima 02 Januari 2021

\section{Kata Kunci :}

Augmented Reality

Fitness

Lansia

Library Kudan SDK

Markerless

\begin{abstract}
Abstrak
Fitness adalah kegiatan pembentukan otot-otot tubuh atau fisik yang dilakukan secara rutin dan berkala, yang bertujuan untuk menjaga fitalitas tubuh agar tetap bugar dan sehat. Lansia merupakan tahap akhir dalam kehidupan manusia ditandai dengan menurunnya kemampuan kerja tubuh akibat penurunan dan perubahan fungsi organ tubuh. Tujuan penelitian ini adalah memanfaatkan teknologi augmented reality sebagai media panduan gerakan fitness untuk manula yang dapat membantu minat lansia untuk menjalankan olahraga kapanpun dan dimanapun agar dapat mengurangi resiko jatuh dan penurunan kekuatan otot serta terhindarnya dari penyakit yang berbahaya. Aplikasi ini menggunakan Library kudan SDK yang mampu menampilkan animasi 3D gerakan fitness manula dengan menggunakan teknik markerless tracking dalam bentuk augmented reality. Hasil dari implementasi teknologi augmented reality yaitu aplikasi panduan fitness untuk manula yang dapat dijalankan pada smartphone dengan sistem operasi android. Setelah dilakukan pengujian dengan black box, fungsi-fungsi tombol pada aplikasi dapat berjalan dengan baik dan menampilkan hasil yang sesuai dengan tujuan yang diharapkan. Aplikasi dapat menampilkan animasi 3D gerakan fitness manula dengan cepat pada siang hari dan malam hari, di dalam maupun di luar ruangan dengan syarat intensitas cahaya diatas 1 lux pada jarak minimal $10 \mathrm{~cm}$ dan maksimal jarak 60 $\mathrm{cm}$ dengan sudut diatas $10^{\circ}$ hingga $90^{\circ}$. Pengujian kuesioner dengan jumlah 5 responden diperoleh hasil jawaban dengan total rata-rata persentase yaitu $87,2 \%$ kriteria sangat baik, maka aplikasi ini dapat dijadikan sebagai media untuk mempelajari gerakan fitness pada manula.
\end{abstract}

(C) This work is licensed under a Creative Commons AttributionShareAlike 4.0 International License.

\section{Koresponden:}

Des Suryani

Program Studi Teknik Informatika, Fakultas Teknik

Universitas Islam Riau

Jl. Kaharuddin Nasution No. 113 Marpoyan, Pekanbaru Riau, Indonesia, 28284

Email : des.suryani@eng.uir.ac.id 


\section{PENDAHULUAN}

Usia lanjut (Lansia) adalah dimana seseorang mengalami pertambahan umur yang disertai penurunan fungsi fisik dan ditandai dengan penurunan masa otot serta kekuatannya, laju denyut jantung maksimal, peningkatan lemak tubuh, dan penurunan fungsi otak. Penurunan tersebut mempengaruhi berbagai jaringan sistem organ dan fungsi yang secara kumulatif dapat mempengaruhi aktifitas hidup sehari-hari. Penurunan struktur fungsi pada lansia dapat dihambat dengan berolahraga secara teratur.

Perkembangan teknologi saat ini semakin berkembang, dimana teknologi informasi sangat berperan penting dalam kehidupan masyarakat. Sehingga tidak heran untuk melakukan kegiatan sehari-hari, dibutuhkan sebuah alat bantu komunikasi telepon genggam yang bisa digunakan kapanpun dan dimanapun. Banyak hal yang dapat dilakukan orang-orang dengan memanfaatkan telepon genggam, seperti mengakses internet, mobile banking, mengolah data, mencatat agenda sehari-hari, menggunakan aplikasi pembelajaran hingga bermain game, dan tentu saja dengan tidak mengesampingkan fungsi utama dari telepon genggam itu sendiri, yaitu sebagai alat telekomunikasi. Perkembangan telepon genggam pada saat ini semakin condong ke arah telepon pintar (smartphone) hal ini dikarenakan smartphone memiliki fasilitas yang dilengkapi dengan dukungan perangkat keras yang lebih modern sehingga mendukung untuk bekerja lebih kompleks. Oleh karena itu pada smartphone banyak digunakan teknologi-teknologi terbaru dalam penyajian informasi untuk pengguna, salah satunya adalah teknologi Augmented Reality.

Pemanfaatan teknologi Augmented Reality dapat digunakan pada bidang edukasi, kesehatan, militer, iklan, hiburan, dan navigasi. Hingga saat ini pengembangan aplikasi Augmented reality dalam bidang-bidang tersebut sudah banyak digunakan salah satunya pada smartphone yang memiliki sistem operasi Android karena Android sendiri bersifat Open Source sehingga lebih mudah dikembangkan. Sistem pembelajaran yang menerapkan teknologi Augmented Reality dalam sistem pencernaan yang merupakan salah satu anatomi manusia dapat membantu pengguna aplikasi mengamati bentuk organ-organ sistem pencernaan secara realtime [1]. Pengembangan Augmented Reality di bidang hiburan maupun pembelajaran masih jarang ditemukan khususnya mengenai Fitness. Aplikasi Augmented Reality berbasis Android pada umumnya dapat ditemui salah satunya di Google Play Store.

Dari permasalahan yang telah dipaparkan sebelumnya, maka peneliti membuat suatu aplikasi Augmented Reality panduan Fitness untuk lansia. Aplikasi ini diharapkan dapat meningkatkan kebugaran pada tubuh lansia khususnya pada penurunan resiko jatuh dan penurunan kekuatan otot pada tubuh lansia sehingga menjadikan lansia sebagai individu yang mandiri, sehat dan tetap aktif. Dengan berolahraga secara teratur merupakan satu alternatif yang efektif dan aman untuk meningkatkan atau mempertahankan kebugaran dan kesehatan jika dikerjakan secara benar. Informasi kesehatan merupakan salah satu hal penting yang harus diketahui dalam upaya menjaga kesehatan karena kesehatan merupakan aset terpenting dalam kehidupan [2]. Di masa depan, teknologi Augmented Reality sebagian besar akan mengubah kehidupan manusia, yaitu tren perkembangan ilmu pengetahuan dan teknologi yang tak terhindarkan [3].

\section{METODE PENELITIAN}

\subsection{Pengumpulan Data}

Dalam proses pembuatan aplikasi panduan fitness untuk manula ini, diperlukan data-data pendukung yang benar dan akurat, oleh karena itu adapun beberapa teknik pengumpulan data yang dilakukan pada penelitian ini adalah sebagai berikut:

1. Pengamatan (Observasi)

Penulis melakukan pengamatan langsung terhadap objek penelitian yaitu dengan melakukan pengamatan pada lansia di lingkungan sekitar.

2. Pengumpulan Data

Data-data yang diperlukan akan dikumpulkan berdasarkan hasil dari pengamatan langsung di lapangan. Dari hasil pengumpulan data, data tersebut akan digunakan sebagai acuan untuk membangun sistem baru yang dapat diimplementasikan. 
3. Penelitian Kepustakaan

Dalam melaksanakan penelitian kepustakaan, penulis melakukan pencarian bahan pada buku, artikel, dan searching internet untuk digunakan sebagai acuan dalam perumusan dan penyelesaian masalah..

\subsection{Konsep Teori}

\subsubsection{Fitness}

Pusat kebugaran (fitness) adalah suatu kegiatan dalam ruangan dengan menawarkan kegiatan olahraga dari yang tanpa menggunakan alat, sampai yang menggunakan alat-alat mahal dan canggih, diantaranya bertujuan prestasi [4]. Aktivitas olahraga fitness dapat membakar lemak, kekuatan fisik bertambah, dapat mencegah penyakit, detoksifikasi, meningkatkan metabolisme, mengurangi stress, meningkatkan konsentrasi, melatih pernapasan [5].

\subsubsection{Lansia}

Lanjut usia (lansia) merupakan tahap akhir dalam kehidupan manusia. Manusia yang memasuki tahap ini ditandai dengan menurunnya kemampuan kerja tubuh akibat perubahan atau penurunan fungsi organ-organ tubuh. Kesehatan olahraga bagi Lansia merupakan hal penting yang harus diprogramkan, baikdari petugas kesehatan, profesional olahraga, maupun masyarakat [6].

Lansia dibagi menjadi tiga golongan:

1. Umur lanjut (elderly) : usia 60-75 tahun

2. Umur tua $($ old $)$ : usia $76-90$ tahun

3. Umur sangat tua (very old) $:$ usia $>90$ tahun

Yang terjadi dengan manusia dalam proses menua secara ringkas dapat dikatakan:

1. Kulit tubuh dapat menjadi lebih tipis, kering dan tidak elastis lagi.

2. Rambut rontok warnanya berubah menjadi putih, kering dantidak mengkilat.

3. Jumlah otot berkurang, ukuran juga mengecil, volume otot secara keseluruhan menyusut dan fungsinya menurun.

4. Otot-otot jantung mengalami perubahan degeneratif, ukuran jantung mengecil, kekuatan memompa darah berkurang.

5. Pembuluh darah mengalami kekakuan (Arteriosklerosis).

6. Terjadinya degenerasi selaput lender dan bulu getar saluran pemapasan, gelembung paruparu menjadi kurang elastis.

7. Tulang-tulang menjadi keropos (osteoporosis).

8. Akibat degenerasi di persendian, permukaan tulang rawan menjadi kasar.

9. Karena proses degenerasi maka jumlah nefron (satuan fungsional di ginjal yang bertugas membersihkan darah) menurun. Yang berakibat kemampuan mengeluarkan sisa metabolism melalui air seni berkurang pula.

Proses penuaan dianggap sebagai peristiwa fisiologik yang memang harus dialami oleh semua makluk hidup

\subsubsection{Augmented Reality}

Augmented reality bertujuan untuk mengembangkan teknologi yang memperbolehkan penggabungan secara real-time terhadap digital content yang dibuat oleh komputer dengan dunia nyata. Augmented reality memperbolehkan pengguna melihat objek maya dua dimensi atau tiga dimensi yang diproyeksikan terhadap dunia nyata.

Dalam penelitian yang dilakukan oleh Putu Agus Mardika Putra, I Gede Mahendra Darmawiguna, dan Gede Aditra Pradnyana (2017) dengan tujuan untuk menarik perhatian masyarakat salah satu olahraga bulutangkis khususnya teknik dasar olahraga bulutangkis 3D sehingga lebih menarik dan lebih nyata. Pembangunan aplikasi ini menggunakan teknik markerless 
dengan dukungan dari vuforia sebagai library dari pembuatan aplikasi tersebut dan unity $3 D$ sebagai tools engine untuk merendering model animasi yang telah dibuat. Letak perbedaan yang mendasar dari penelitian yang akan dilakukan terdapat pada teknik tracking marker yang digunakan untuk membangun aplikasi tersebut[7].

Penerapan aplikasi Augmented Reality (AR) juga dapat diujicobakan pada perangkat Android lain dengan spesifikasi yang berbeda dapat berjalan dengan baik dan beroperasi dengan lancar [8].

Pengembangan teknologi AR dapat memenuhi kebutuhan peningkatan kognitif, afektif dan psikomotorik dalam kegiatan pembelajaran yang menggunakan metode scientific approach [9]. menghadirkan aplikasi AR pendidikan baru, dan mengisi kesenjangan dalam teknologi pendidikan bidang [10].

\subsection{Use Case Diagram}

Use case Diagram menggambarkan fungsionalitas yang diharapkan dari sebuah sistem, yaitu bagaimana cara pengguna berinteraksi dengan sistem yang akan dibuat. Sehingga pengguna bisa mengetahui apa saja interaksi yang bisa terjadi. Adapun tampilan use case diagram aplikasi dapat dilihat pada gambar 1 .

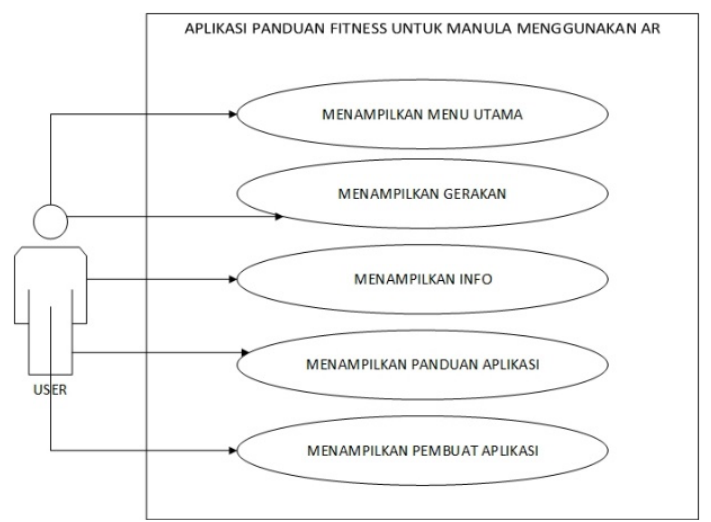

Gambar 1. Use Case Diagram

\subsection{Activity Diagram}

Pada activity diagram aplikasi panduan fitness untuk manula menggunakan augmented reality penggambaran diagram menunjukkan bagaimana aktifitas yang terjadi ketika pengguna menjalankan aplikasi tersebut. Activity diagram menu utama menampilkan alur aplikasi untuk menampilkan menu utama, dimana menu utama adalah menu awal ketika membuka aplikasi. Pada menu utama terdapat beberapa menu yaitu menu gerakan, menu info, menu panduan, dan menu pembuat, serta adanya button keluar untuk keluar dari aplikasi yang dapat dilihat pada gambar 2 .

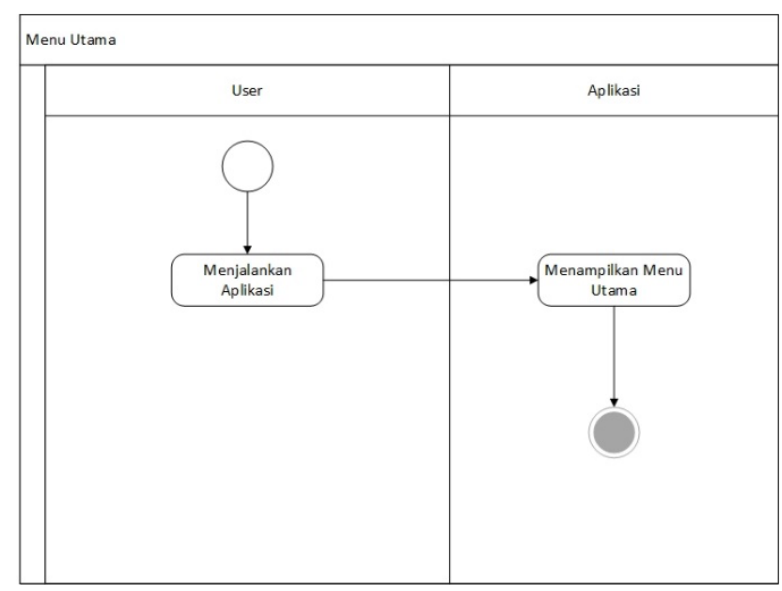

Gambar 2. Activity Diagram Menu Utama 
Activity diagram menu gerakan menampilkan alur aplikasi untuk menampilkan menu gerakan. Pada menu gerakan, aplikasi akan menampilkan 2 bagian gerakan fitness lansia. Ketika user memilih salah-satu gerakan maka aplikasi akan menampilkan kamera dan kemudian user menetapkan marker lalu aplikasi akan mendeteksi marker dan object 3D animasi gerakan akan tampil beserta info gerakan yang dapat dilihat pada gambar 3 .

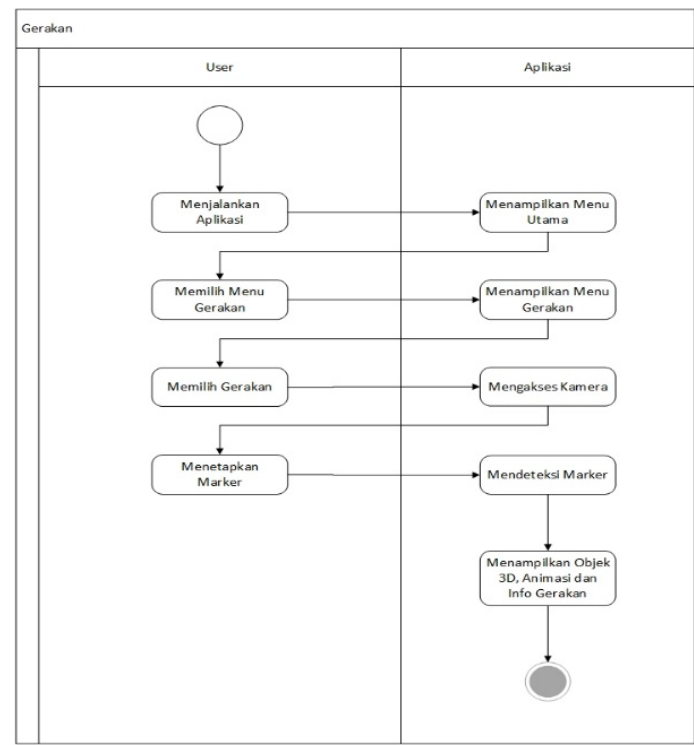

Gambar 3. Activity Diagram Menu Gerakan

Activity Diagram info menampilkan alur aplikasi untuk menampilkan menu info, dimana menu info berisi informasi tentang fitness pada lansia serta manfaat bagi tubuh yang dapat dilihat pada gambar 4.

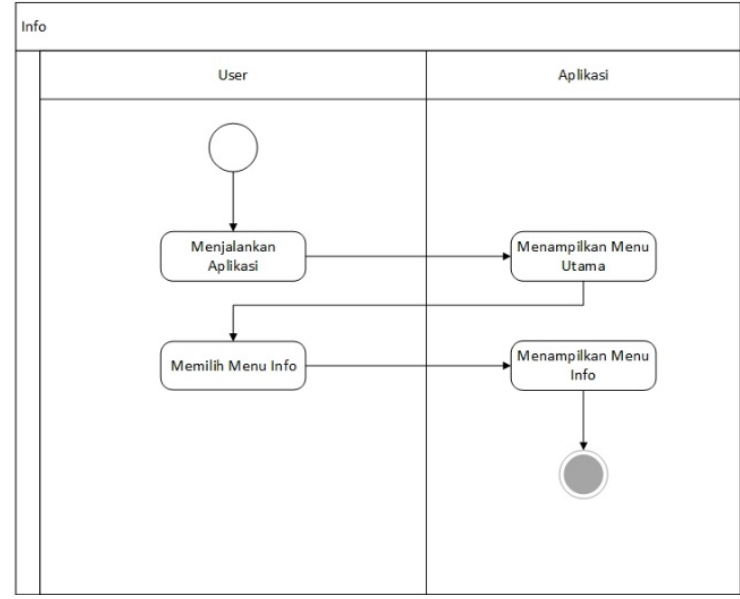

Gambar 4. Activity Diagram Menu Info

Activity Diagram panduan menampilkan alur aplikasi untuk menampilkan menu panduan, dimana menu panduan berisi tentang petunjuk penggunaan aplikasi yang dapat dilihat pada gambar 5. 


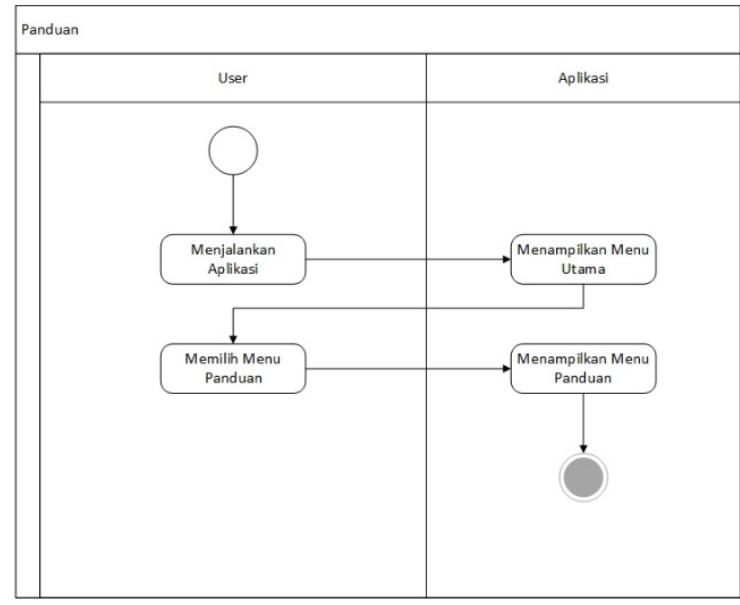

Gambar 5. Activity Diagram Menu Panduan

\subsection{Program Flowchart}

Perancangan aplikasi pada penelitian ini menggunakan program flowchart yang digunakan untuk menunjukkan alur kerja program secara keseluruhan. Desain logika program panduan fitness manula menggunakan augmented reality dapat dilihat pada gambar 6 dan 7.

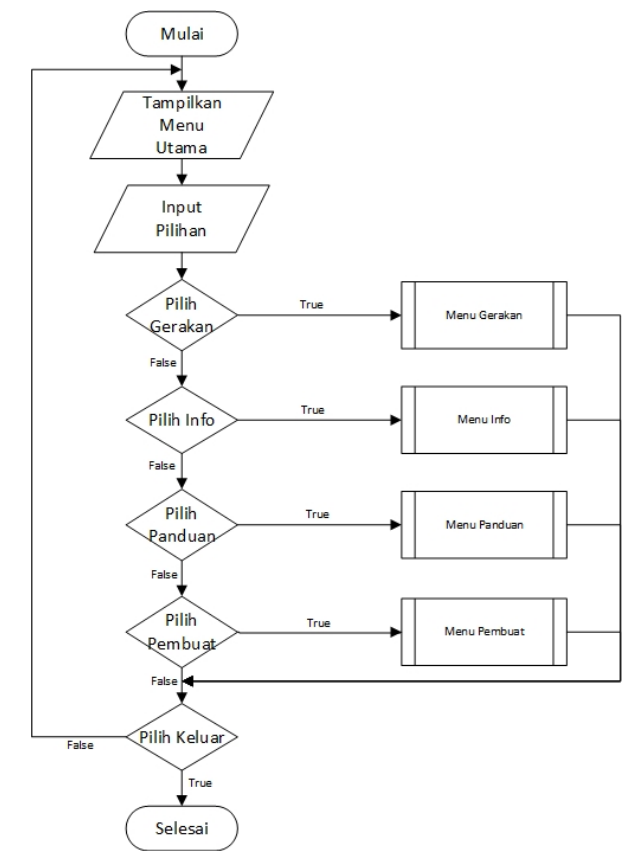

Gambar 6. Program Flowchart Menu Utama 


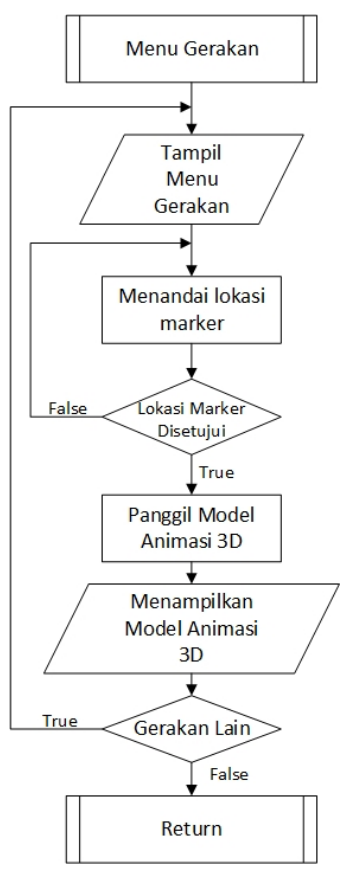

Gambar 7. Program Flowchart Menu Gerakan

\section{HASIL DAN PEMBAHASAN}

\subsection{Tampilan Awal Aplikasi}

Pada halaman ini akan tampil logo dari aplikasi panduan fitness manula dan bar loading, saat bar loading penuh, maka pengguna akan dihadapkan dengan halaman menu awal aplikasi panduan fitness manula yang dapat dilihat pada gambar 8 .

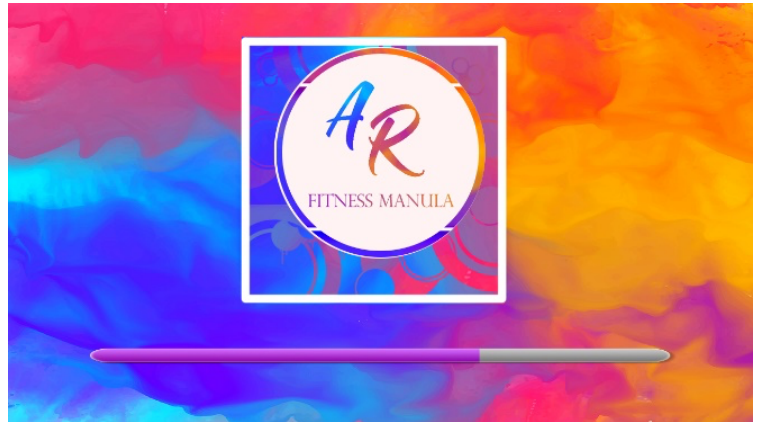

Gambar 8. Tampilan Awal Aplikasi

\subsection{Tampilan Halaman Menu Aplikasi}

Pada halaman ini terdapat beberapa button yaitu button gerakan, button info, button panduan, button pembuat. Fungsi button gerakan yaitu untuk menampilkan menu gerakan fitness manula, button Info untuk menampilkan menu informasi dari gerakan fitness manula serta manfaat dari gerakan tersebut, button panduan untuk menampilkan menu panduan penggunaan aplikasi, button pembuat untuk menampilkan menu pembuat (author) dari aplikasi panduan fitness manula, dan button keluar digunakan untuk keluar dari aplikasi panduan fitness manula yang dapat dilihat pada gambar 9. 


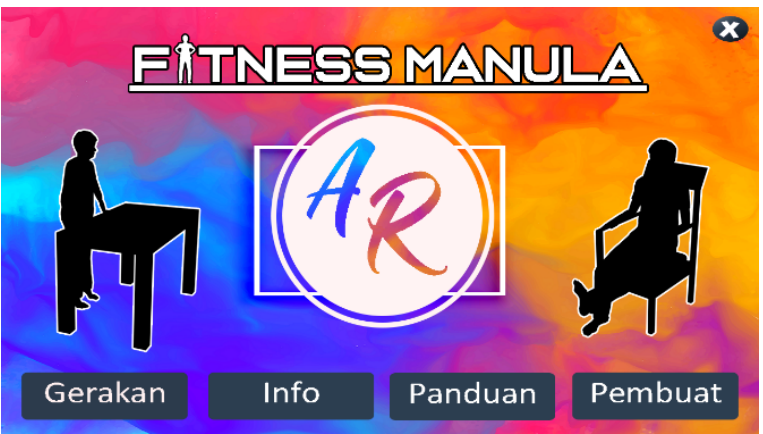

Gambar 9. Tampilan Halaman Menu Aplikasi

\subsection{Tampilan Panel Gerakan}

Pada panel ini terdapat 2 bagian gerakan fitness manula yaitu balance dan strength. Pada bagian balance terdapat 4 button gerakan diantaranya button gerakan Sit to Stand, button gerakan Sideways Walking, button gerakan Heel Toe Tandem Standing, button gerakan Heel Toe Tandem Walking, dan pada bagian strength terdapat 4 button gerakan diantaranya button gerakan Side Hip Strengthening exercise, button gerakan Front Knee Strengthening exercise, button gerakan Heel Raises, dan button gerakan Toe Raises. Setiap button tersebut berfungsi untuk menampilkan halaman menu gerakan panduan fitness manula yang dapat dilihat pada gambar 10 .

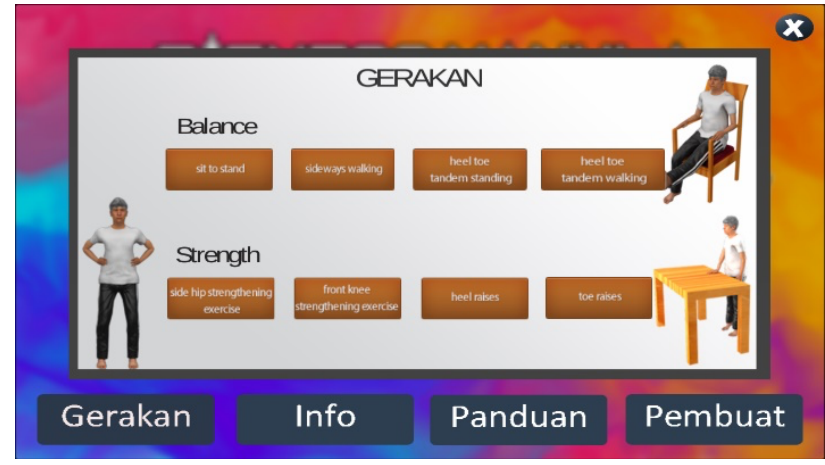

Gambar 10. Tampilan Panel Gerakan

\subsection{Tampilan Panel Info}

Pada panel info ini berisi text informasi gerakan fitness manula serta kegunaan dari gerakan tersebut yang dapat dilihat pada gambar 11 .

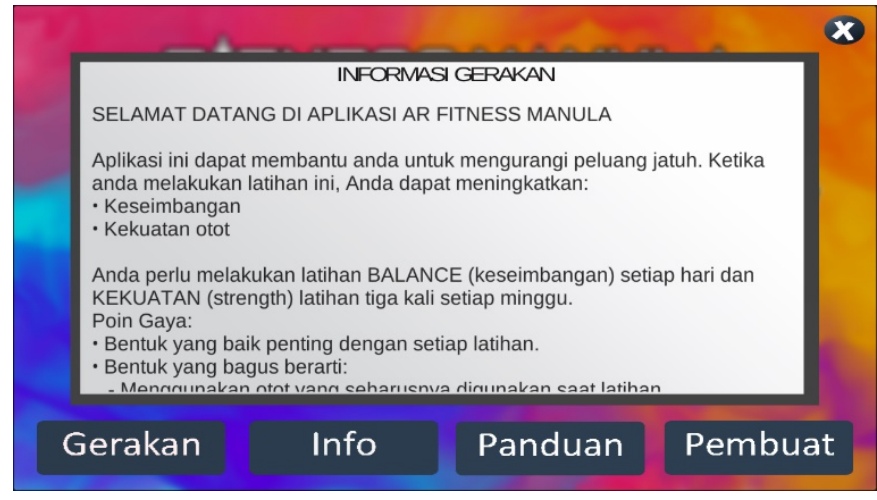

Gambar 11. Tampilan Panel Info

\subsection{Tampilan Panel Panduan}

Panel ini berisi text informasi petunjuk penggunaan aplikasi dan penjelasan dari fungsifungsi tombol yang ada pada aplikasi panduan fitness manula yang dapat dilihat pada gambar 12 . 


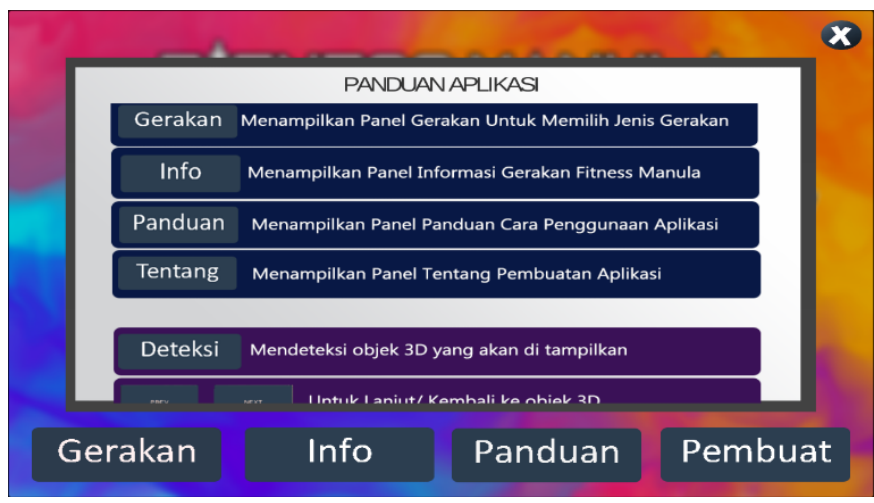

Gambar 12. Tampilan Panel Panduan

\subsection{Tampilan Animasi AR Gerakan}

Tampilan animasi AR gerakan fitness manula dapat dilihat pada gambar 13. Animasi akan tampil ketika pengguna menekan tombol deteksi pada aplikasi dan terpadat nya button informasi yang akan menampilkan informasi pada gerakan.

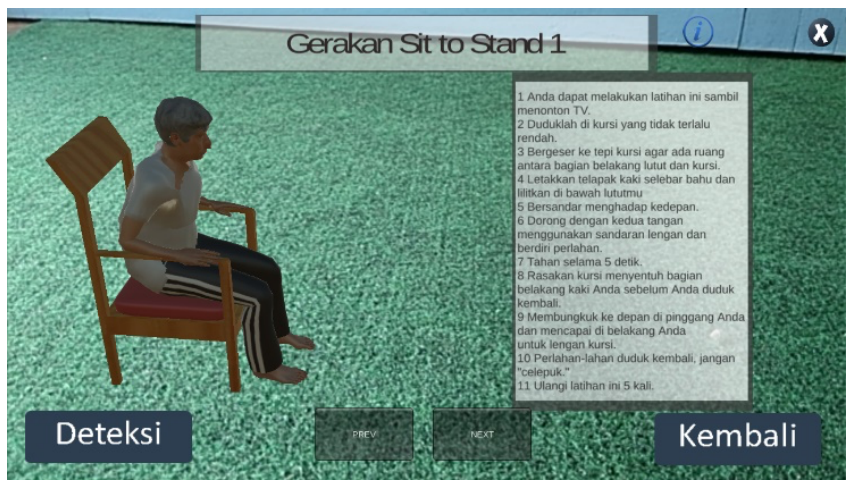

Gambar 13. Tampilan Animasi AR Gerakan

\subsection{Pengujian Aplikasi}

Pengujian pada aplikasi menggunakan pengujian black box bertujuan untuk menguji setiap button yang ada pada aplikasi yang dapat dilihat pada tabel 1 .

Tabel 1. Hasil Pengujian Aplikasi

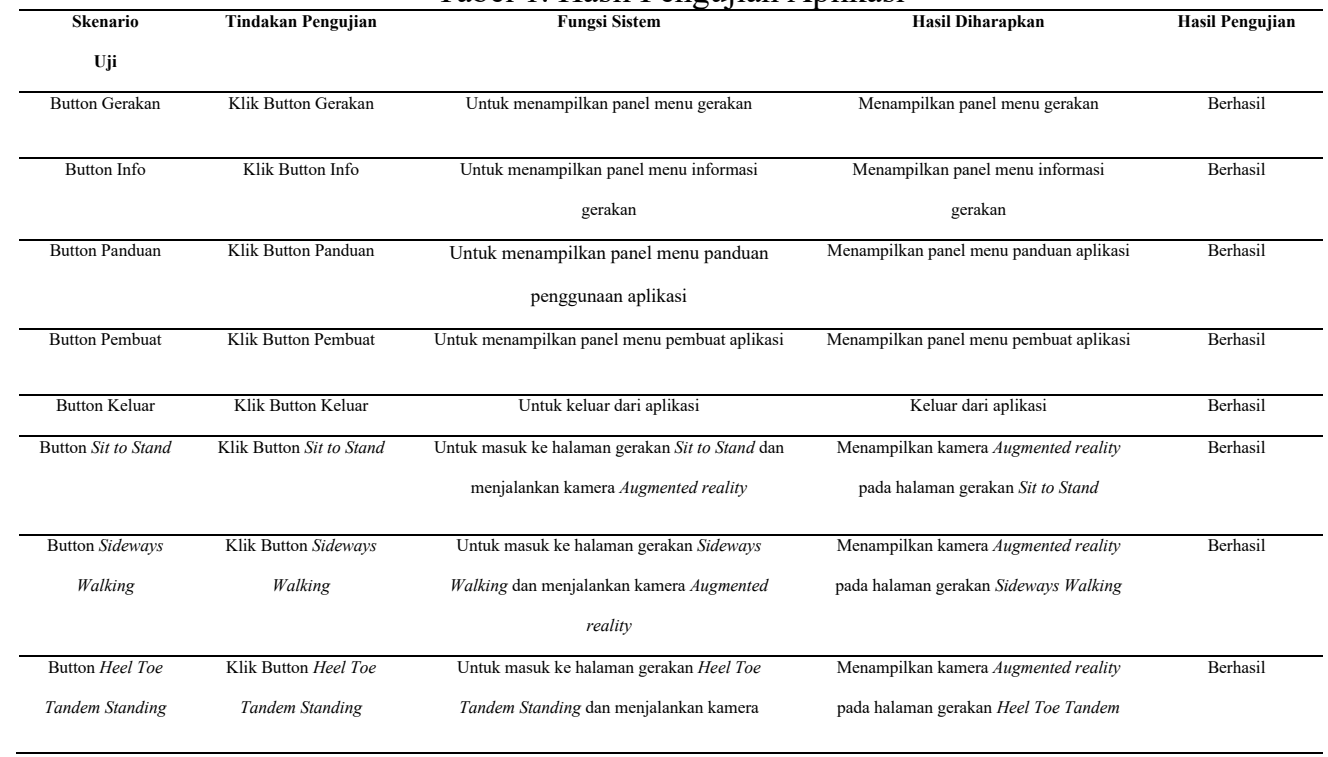




\begin{tabular}{|c|c|c|c|c|}
\hline & & Augmented reality & Standing & \\
\hline $\begin{array}{l}\text { Button Heel Toe } \\
\text { Tandem Walking }\end{array}$ & $\begin{array}{c}\text { Klik Button Heel Toe } \\
\text { Tandem Walking }\end{array}$ & $\begin{array}{c}\text { Untuk masuk ke halaman gerakan Heel Toe } \\
\text { Tandem Walking dan menjalankan kamera } \\
\text { Augmented reality }\end{array}$ & $\begin{array}{c}\text { Menampilkan kamera Augmented reality } \\
\text { pada halaman gerakan Heel Toe Tandem } \\
\text { Walking }\end{array}$ & Berhasil \\
\hline $\begin{array}{l}\text { Button Side Hip } \\
\text { Strengthening } \\
\text { Exercise }\end{array}$ & $\begin{array}{l}\text { Klik Button Side Hip } \\
\text { Strengthening Exercise }\end{array}$ & $\begin{array}{l}\text { Untuk masuk ke halaman gerakan Side Hip } \\
\text { Strengthening Exercise dan menjalankan kamera } \\
\text { Augmented reality }\end{array}$ & $\begin{array}{c}\text { Menampilkan kamera Augmented reality } \\
\text { pada halaman gerakan Side Hip } \\
\text { Strengthening Exercise }\end{array}$ & Berhasil \\
\hline $\begin{array}{c}\text { Button Front Knee } \\
\text { Strengthening } \\
\text { Exercise }\end{array}$ & $\begin{array}{l}\text { Klik Button Front Knee } \\
\text { Strengthening Exercise }\end{array}$ & $\begin{array}{l}\text { Untuk masuk ke halaman gerakan Front Knee } \\
\text { Strengthening Exercise dan menjalankan kamera } \\
\text { Augmented reality }\end{array}$ & $\begin{array}{c}\text { Menampilkan kamera Augmented reality } \\
\text { pada halaman gerakan Front Knee } \\
\text { Strengthening Exercise }\end{array}$ & Berhasil \\
\hline $\begin{array}{c}\text { Button Heel } \\
\text { Raises }\end{array}$ & Klik Button Heel Raises & $\begin{array}{c}\text { Untuk masuk ke halaman gerakan Heel Raises dan } \\
\text { menjalankan kamera Augmented reality }\end{array}$ & $\begin{array}{c}\text { Menampilkan kamera Augmented reality } \\
\text { pada halaman gerakan Heel Raises }\end{array}$ & Berhasil \\
\hline Button Toe Raises & Klik Button Toe Raises & $\begin{array}{c}\text { Untuk masuk ke halaman gerakan Toe Raises dan } \\
\text { menjalankan kamera Augmented reality }\end{array}$ & $\begin{array}{c}\text { Menampilkan kamera Augmented reality } \\
\text { pada halaman gerakan Toe Raises }\end{array}$ & Berhasil \\
\hline
\end{tabular}

\section{KESIMPULAN}

Berdasarkan hasil pengujian pada aplikasi panduan fitness manula berbasis Augmented reality, maka dapat diambil kesimpulan sebagai berikut:

1. Penggunaan aplikasi panduan fitness manula berbasis augmented reality dapat membantu manula untuk melakukan fitness di rumah yang bertujuan untuk mencegah penurunan masa otot dan kekuatan keseimbangan badan.

2. Pengujian tracking penandaan markerless aplikasi panduan fitness manula dapat menampilkan objek animasi 3D dengan cepat pada siang hari dan malam hari, di dalam maupun di luar ruangan dengan syarat intensitas cahaya di atas 1 lux.

3. Selain intensitas cahaya, jarak dan sudut deteksi tracking penandaan markerless pada aplikasi panduan fitness manula dapat menampilkan animasi 3D dengan baik pada jarak minimal $10 \mathrm{~cm}$ dan maksimal jarak $60 \mathrm{~cm}$ dengan sudut diatas $10^{\circ}$ hingga $90^{\circ}$.

4. Berdasarkan pengujian fungsi tombol, aplikasi panduan fitness manula berbasis augmented reality berjalan dengan baik sehingga semua tombol dapat digunakan dan menampilkan hasil yang sesuai dengan tujuan yang diharapkan.

\section{UCAPAN TERIMA KASIH}

Penulis mengucapkan terima kasih kepada Universitas Islam Riau yang telah memberi dukungan financial terhadap penelitian ini

\section{DAFTAR PUSTAKA}

[1] F. Z. Adami and C. Budihartanti, "Penerapan Teknologi Augmented Reality Pada Media Pembelajaran Sistem Pencernaan Berbasis Android,” Tek. Komput. AMIK BSI, vol. 2, no. 1, pp. 122 $131,2016$.

[2] Z. S. Jamil, D. Irfan, and T. Sriwahyuni, "Perancangan Sistem Informasi Pemetaan Fasilitas Kesehatan Kota Padang Berbasis Web Dengan Memanfaatkan Google Maps API," J. Vokasional Tek. Elektron. Inform., vol. 3, no. 1, pp. 1-10, 2015.

[3] Y. Chen, Q. Wang, H. Chen, X. Song, H. Tang, and M. Tian, "An overview of augmented reality technology," J. Phys. Conf. Ser., vol. 1237, no. 2, 2019, doi: 10.1088/1742-6596/1237/2/022082.

[4] R. Indarwati, M. Psik, and F. K. Unair, "Peningkatan Stabilitas Postural Pada Lansia Melalui Balance Exercise," Nurse Media J. Nurs., vol. 1, no. 2, pp. 59-68, 2010, doi: 10.14710/nmjn.v1i2.716.

[5] L. Danang Sutawijaya and S. Riyadi, "Prosiding Seminar Nasional Rekarta 2020 Menjaga Kebugaran Jasmani Melalui Aktivitas Fisik Di Fitness Center," pp. 6-7, 2020.

[6] D. Kurnianto, "Menjaga Kesehatan Di Usia Lanjut," J. Olahraga Prestasi, vol. 11, no. 2, p. 115182, 2015, doi: 10.21831/jorpres.v11i2.5725.

[7] B. H. A. P. I. Gst, I. G. M. Darmawiguna, and S. Kom, "Pengembangan Aplikasi Augmented Reality 
Markerless Pengenalan Dan Teknik Dasar Bola Basket," KARMAPATI (Kumpulan Artik. Mhs. Pendidik. Tek. Inform., vol. 6, no. 3, pp. 247-355, 2017.

[8] A. Winatra, S. Sunardi, R. Khair, I. Idris, and A. Santosa, “Aplikasi Augmented Reality (Ar) Sebagai Media Edukasi Pengenalan Bentuk Dan Bagian Pesawat Berbasis Android," J. Teknol. Inf., vol. 3, no. 2, p. 212, 2019, doi: 10.36294/jurti.v3i2.1217.

[9] M. Mantasia and H. Jaya, "Pengembangan Teknologi Augmented Reality Sebagai Penguatan Dan Penunjang Metode Pembelajaran Di Smk Untuk Implementasi Kurikulum 2013," J. Pendidik. Vokasi, vol. 6, no. 3, p. 281, 2016, doi: 10.21831/jpv.v5i3.10522.

[10] R. M. Yilmaz, "Educational magic toys developed with augmented reality technology for early childhood education," Comput. Human Behav., vol. 54, pp. 240-248, 2016, doi: 10.1016/j.chb.2015.07.040.

\section{BIOGRAFI PENULIS}

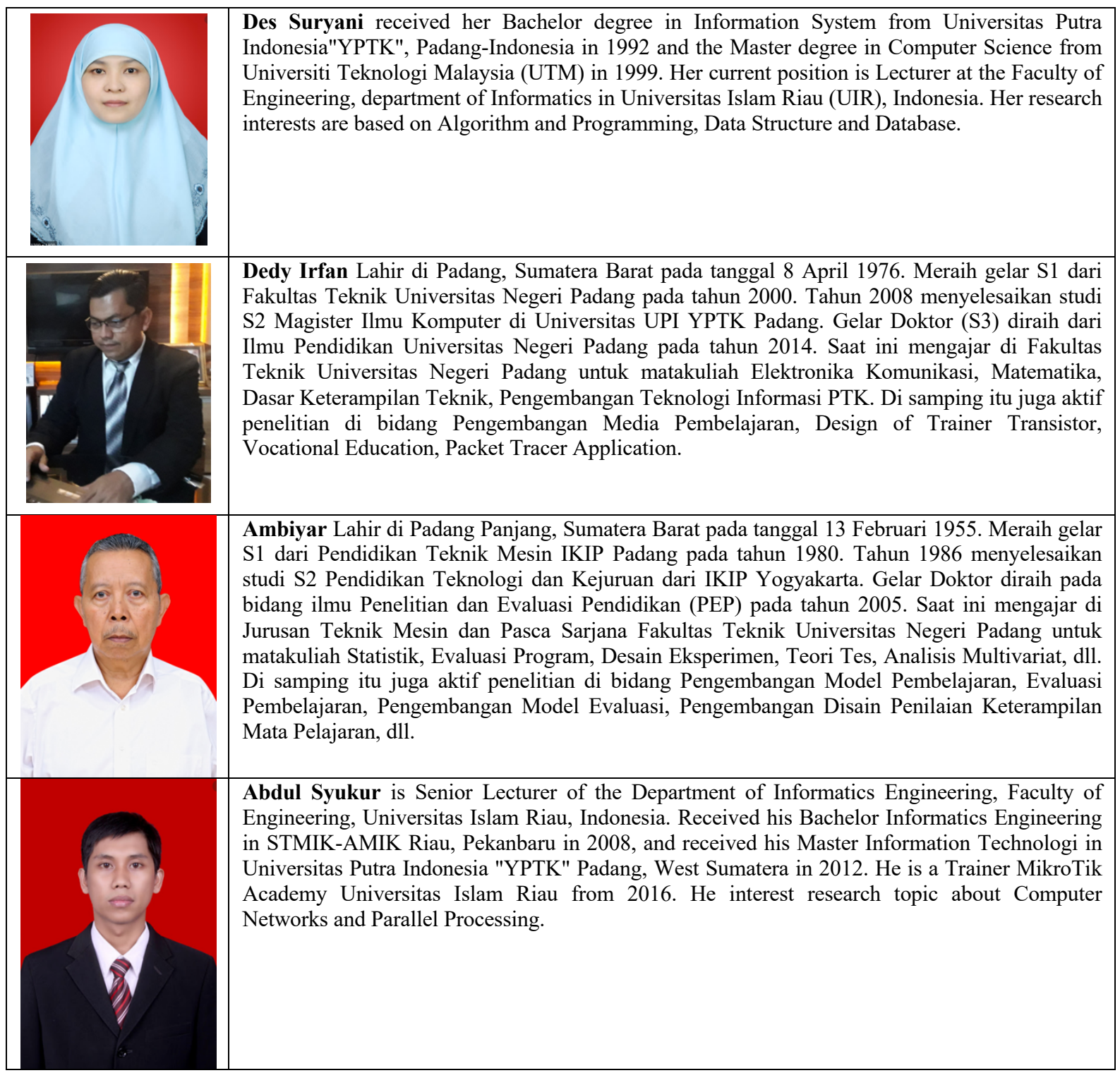

